\title{
“On-water” Hiyama coupling catalyzed by CNC pincer complexes of Pd(II)
}

\author{
Blanca Inés, Maria Jesús Moure, Raul SanMartin,* \\ Maria Teresa Herrero, Isabel Moreno, and Esther Domínguez*
}

Kimika Organikoa II Saila, Zientzia eta Teknologia Fakultatea, Euskal Herriko Unibertsitatea, Sarriena auzoa, z/g 48940 Leioa, Bizkaia, Spain

E-mail: raul.sanmartin@ehu.es

\section{Dedicated to Professor Julio Alvárez Builla on the occasion of his $65^{\text {th }}$ birthday}

\begin{abstract}
The catalytic activity of two hydrophilic CNC-type palladium pincer complexes is evaluated in the coupling between trimethoxyphenylsilane and aryl bromides. A wide range of assays is performed for each palladium source, and alkaline aqueous conditions turn out to be the most efficient for the target Hiyama coupling, which is applied to the synthesis of several biaryls. In addition, the direct reuse of the aqueous layer containing the catalyst is also conducted with good yield.
\end{abstract}

Keywords: Cross-coupling, Hiyama coupling, biaryl synthesis, palladium pincer complexes, "on-water" chemistry

\section{Introduction}

The palladium-catalyzed C-C bond formation between aryl, alkenyl, or alkyl halides or pseudohalides and organosilanes, first reported by Yasuo Hatanaka and Tamejiro Hiyama in 1988, is a powerful, alternative procedure to other established procedures like Suzuki or Stille couplings. ${ }^{1}$ Although the presence of fluoride ions $\left(\mathrm{KF}, \mathrm{Bu}_{4} \mathrm{NF}\right.$, etc.) was a requirement for the transmetallation step in the initial reports, later it was discovered that sodium or potassium hydroxide could replace the later reagents/additives for this task. ${ }^{1 b, 2}$ Similarly, several improvements to the initial conditions have been made in the last decades, and several palladium sources and ligands have been employed so far in this context. ${ }^{3}$

In contrast with other palladium-catalyzed cross-coupling reactions, very scarce examples of the use of pincer complexes in Hiyama couplings can be found in the literature. ${ }^{4}$ Palladium pincer complexes (palladacycles containing tridentate ligands) have become a very promising 
family of complexes due to an excellent balance between stability and reactivity that enables them to catalyze a number of organic reactions. ${ }^{5}$

Recently we published the synthesis and catalytic activity of two new hydrophilic CNC pincers 1-2. ${ }^{6}$ On the basis of their excellent catalytic behavior in the Suzuki-type coupling between aryl halides or benzyl halides and arylboronic acids, we envisaged the application of the aforementioned pincers 1-2 to Hiyama reaction. The most remarkable results of such catalytic evaluation are displayed in this paper.

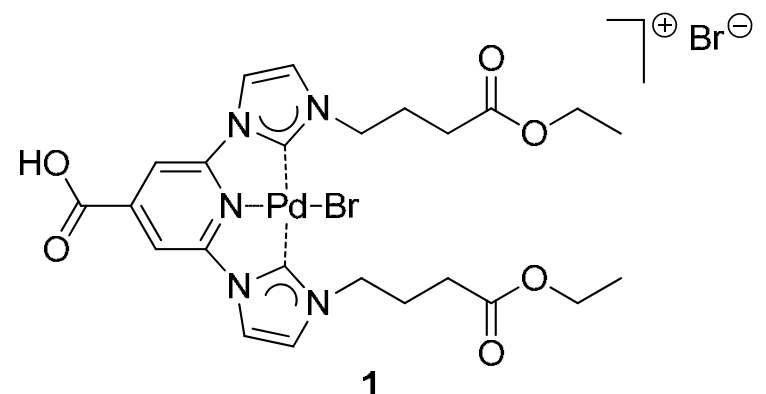

1

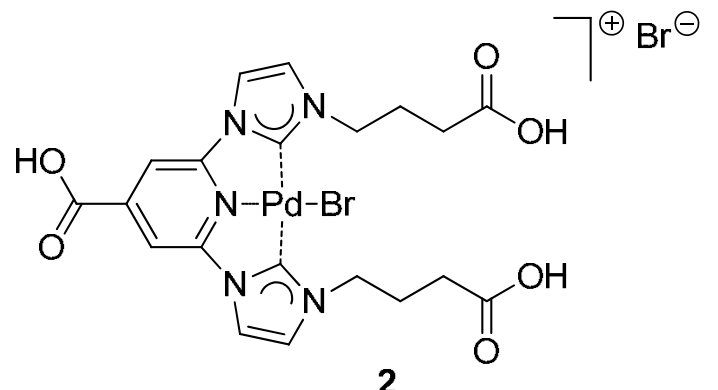

2

\section{Results and Discussion}

Among different organosilane derivatives (arylhalosilanes, aryl(halo)silacyclobutanes, aryl(triallyl)silanes, aryl(dimethyl)silanols, aryl bis(catechol) silicates and trialkoxy(aryl)silanes), we chose the latter compounds as reagents due to their commercial availability, lower price and higher stability under a wide variety of reaction conditions. Thus, taking 4-bromoacetophenone 3a and trimetoxy(pheny)silane $\mathbf{4}$ as model substrates, a whole array of reaction conditions were initially assayed employing complex $\mathbf{1}$ as the palladium source. Following our research on the application of sustainable media to cross coupling reactions, ${ }^{7}$ most of the assays based on hydroxide bases were conducted in aqueous media, and polyethylene glycol 400 (PEG 400) ${ }^{8}$ was also employed in this context. A selection of such coupling assays is displayed in Table 1.

As initial fluoride ion-mediated assays only provided traces of the target biaryl 5a (Table 1, entries 1-3), aqueous sodium hydroxide was employed in the rest of experiments. The effect of the amount of this base in the reaction outcome was evaluated (entries 4-6) as well as that of other factors like its concentration, number of equivalents of silane $\mathbf{4}$, catalyst loading and temperature (entries 8-10). In an attempt to further decrease the required amount of the complex 1, PEG 400 was added as an additive/co-solvent so that it was possible to effect the target transformation by using a $0.1 \mathrm{~mol} \%$ of catalyst 1 (entry 13). Considering the simplicity and lower basicity of the exclusively aqueous conditions displayed in entry 9 (4 eq. 4a, 3.0 eq. aq. $\mathrm{NaOH} 0.5 \mathrm{M}, 0.3 \mathrm{~mol} \% 1,160^{\circ} \mathrm{C}, 2 \mathrm{~h}$ ), they were elected as the most convenient for Hiyama couplings catalyzed by complex 1 . 
Table 1. Complex 1-catalyzed Hiyama coupling assays

\begin{tabular}{|c|c|c|}
\hline & $3 \mathbf{a}$ & $5 \mathbf{a}$ \\
\hline Entry & Reaction conditions ${ }^{\mathrm{a}}$ & $5 a(\%)^{b}$ \\
\hline 1 & 1.2 eq. $4,2.0$ eq. TBAF, 4 mol $\% 1, o$-xylene, $80^{\circ} \mathrm{C}, 4 \mathrm{~h}$ & $-{ }^{c}$ \\
\hline 2 & 1.2 eq. $4,2.0$ eq. TBAF, 4 mol\% 1 , THF, r.t., 14 h & $-{ }^{c}$ \\
\hline 3 & 1.2 eq. $4,2.0$ eq. TBAF, 2 mol\% $1,1,4$-dioxane, $80^{\circ} \mathrm{C}, 2 \mathrm{~h}$ & $-{ }^{c}$ \\
\hline 4 & 1.2 eq. $4,5.0$ eq. aq. $\mathrm{NaOH} 2 \mathrm{M}, 1 \mathrm{~mol} \% \mathbf{1}, 150^{\circ} \mathrm{C}, 2 \mathrm{~h}$ & $-{ }^{c}$ \\
\hline 5 & 1.2 eq. $4,8.0$ eq. aq. $\mathrm{NaOH} 2 \mathrm{M}, 1 \mathrm{~mol} \% \mathbf{1}, 150^{\circ} \mathrm{C}, 2 \mathrm{~h}$ & 11 \\
\hline 6 & 1.2 eq. $4,12.0$ eq. aq. $\mathrm{NaOH} 2 \mathrm{M}, 1 \mathrm{~mol} \% \mathbf{1}, 150^{\circ} \mathrm{C}, 2 \mathrm{~h}$ & 18 \\
\hline 7 & 4 eq. $4,12.0$ eq. aq. $\mathrm{NaOH} 2 \mathrm{M}, 0.5 \mathrm{~mol} \% 1,150^{\circ} \mathrm{C}, 4 \mathrm{~h}$ & $>99$ \\
\hline 8 & 4 eq. $4,12.0$ eq. aq. $\mathrm{NaOH} 2 \mathrm{M}, 0.1 \mathrm{~mol} \% \mathbf{1}, 150^{\circ} \mathrm{C}, 4 \mathrm{~h}$ & 29 \\
\hline 9 & 4 eq. $4,3.0$ eq. aq. $\mathrm{NaOH} 0.5 \mathrm{M}, 0.3 \mathrm{~mol} \% 1,160^{\circ} \mathrm{C}, 2 \mathrm{~h}$ & $>99$ \\
\hline 10 & 4 eq. $4,3.0$ eq. aq. $\mathrm{NaOH} 0.5 \mathrm{M}, 0.1 \mathrm{~mol} \% 1,160^{\circ} \mathrm{C}, 2 \mathrm{~h}$ & 11 \\
\hline 11 & $\begin{array}{l}4 \text { eq. } 4,5.0 \text { eq. aq. } \mathrm{NaOH} 0.5 \mathrm{M}, 1 \text { eq. } \mathrm{PEG} 400,0.1 \mathrm{~mol} \% \mathbf{1} \text {, } \\
150^{\circ} \mathrm{C}, 1 \mathrm{~h}\end{array}$ & $-c$ \\
\hline 12 & $\begin{array}{l}4 \text { eq. } 4,5.0 \text { eq. aq. } \mathrm{NaOH} 0.5 \mathrm{M}, 2.5 \text { eq. } \mathrm{PEG} 400,0.1 \mathrm{~mol} \% \\
1,150^{\circ} \mathrm{C}, 1 \mathrm{~h}\end{array}$ & 15 \\
\hline 13 & $\begin{array}{l}4 \text { eq. } 4,5.0 \text { eq. aq. } \mathrm{NaOH} 0.5 \mathrm{M}, 7.5 \text { eq. } \mathrm{PEG} 400,0.1 \mathrm{~mol} \% \\
1,150^{\circ} \mathrm{C}, 2 \mathrm{~h}\end{array}$ & $>99$ \\
\hline 14 & $\begin{array}{l}4 \text { eq. } 4,12.0 \text { eq. aq. } \mathrm{NaOH} 0.5 \mathrm{M}, 7.5 \text { eq. } \mathrm{PEG} 400,0.01 \\
\mathrm{~mol} \% \mathbf{1}, 150^{\circ} \mathrm{C}, 2 \mathrm{~h}\end{array}$ & 14 \\
\hline 15 & $\begin{array}{l}4 \text { eq. } 4,12.0 \text { eq. aq. } \mathrm{NaOH} 0.5 \mathrm{M}, 10 \text { eq. } \mathrm{PEG} 400,0.01 \\
\mathrm{~mol} \% \mathbf{1}, 150^{\circ} \mathrm{C}, 2 \mathrm{~h}\end{array}$ & 38 \\
\hline 16 & $\begin{array}{l}4 \text { eq. } 4,12.0 \text { eq. aq. } \mathrm{NaOH} 0.5 \mathrm{M}, 50 \text { eq. } \mathrm{PEG} 400,0.01 \\
\mathrm{~mol} \% \mathbf{1}, 150^{\circ} \mathrm{C}, 2 \mathrm{~h}\end{array}$ & $-c$ \\
\hline 17 & $\begin{array}{l}4 \text { eq. } 4,12.0 \text { eq. aq. } \mathrm{NaOH} 0.5 \mathrm{M}, 10 \text { eq. } \mathrm{PEG} 400,0.01 \\
\mathrm{~mol} \% \mathbf{1}, 150^{\circ} \mathrm{C}, 24 \mathrm{~h}\end{array}$ & $-c$ \\
\hline
\end{tabular}

${ }^{a}$ Reactions were conducted in a sealed tube using 1.0 eq. of 4-bromoacetophenone 3a. ${ }^{b}$ Determined by ${ }^{1} \mathrm{H}$ NMR spectroscopy on the basis of the amount of starting aryl bromide. Diethylene glycol dimethyl ether was used as internal standard. ${ }^{c}$ Complex mixture where only traces of 5a were detected.

A more reduced range of assays were performed by using the more polar CNC complex pincer 2, which also incorporated $N$-heterocyclic carbene moities in its structure. As a precedent of the use of NHCs in Hiyama coupling, an interesting arylation catalyzed by a ( $\mathrm{NHC}$ ) $\mathrm{PdCl}_{2}$ (pyridine) precatalyst in a $\mathrm{H}_{2} \mathrm{O}$ :dioxane mixture had been recently published. ${ }^{\text {a }}$ From 
the results displayed in Table 2, it can be concluded that complex 2 catalyzes the target reaction with similar efficiency, although some slight differences can be detected. Thus, complex 2 is more effective when lower amounts of phenylsilane 4a are employed (Table 2, entries 1, 4, 5, 6 and 7 vs Table 1, entries 1, 4-6), thus suggesting a higher reaction rate that could be related to a faster release of palladium nanoparticles in the reaction medium. ${ }^{9}$ Another interesting effect is that of the requirement of more basic conditions when using 2, as shown by the higher amounts and/or concentrations of $\mathrm{NaOH}$ needed with this latter complex (Table 2, entries 4, 9-11 vs Table 1, entries 4, 9-10). In this case, a possible explanation relies on the additional acidic (carboxy) groups present in pincer 2 that increase its solubility in basic aqueous media. ${ }^{10}$

Table 2. Complex 2-catalyzed Hiyama coupling assays

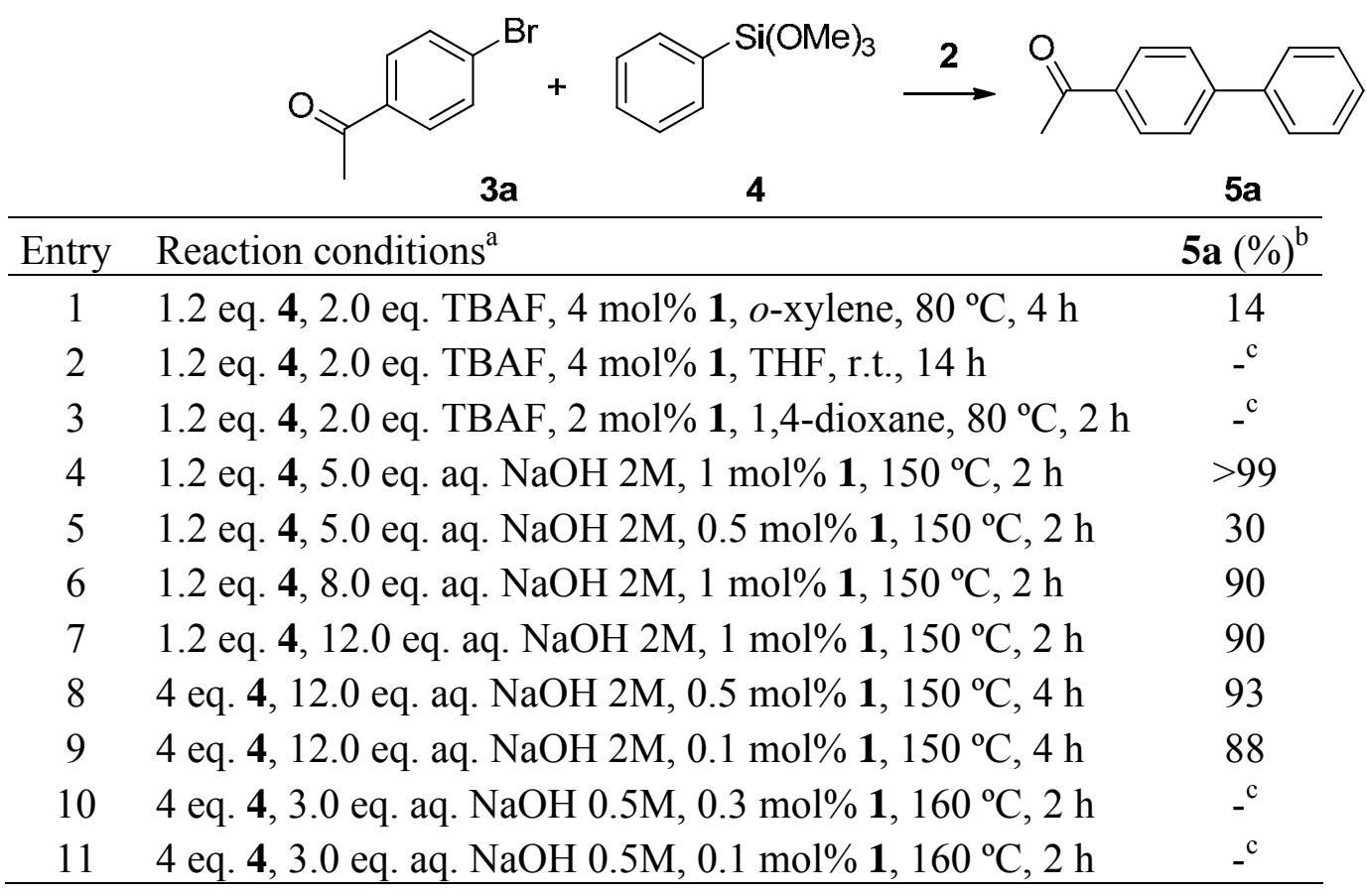

${ }^{a}$ Reactions were conducted in a sealed tube using 1.0 eq. of 4-bromoacetophenone 3a. ${ }^{b}$ Determined by ${ }^{1} \mathrm{H}$ NMR spectroscopy on the basis of the amount of starting aryl bromide. Diethylene glycol dimethyl ether was used as internal standard. ${ }^{\mathrm{C}}$ Complex mixture where only traces of $5 \mathbf{a}$ were detected.

A competition between the target coupling and other side-reactions was noticed, particularly in those assays that provided low or negligible yields (Table 1, entries 1-6, 8, 10-12, 14-17 and Table 2, entries 1-3, 5 10-11). In most cases decomposition of phenylsilane 4 was observed under reaction conditions (unlike ketone 3a, silane $\mathbf{4}$ could not be recovered from the reaction mixture), and to a lower extent, the dehalogenation product from the haloarene 3a (acetophenone) was also detected. 
With these preliminary results in hand, the optimized conditions for each palladium complex (Table 1, entry 9 for $\mathbf{1}$ (Method $A$ ) and Table 2, entry 4 for $\mathbf{2}$ (Method B)) were applied to several electronically dissimilar aryl bromides in order to explore the scope of the method. As shown in Table 3, pincer complex 1 provided better yields in most cases, thus resulting a more general catalyst or precatalyst for the transformation under study. No clear differences can be noted for the reaction outcome from electron-donor and electron-withdrawing substituents, and the poor yield obtained from nitro derivative $\mathbf{3 b}$ could be caused by a nitro-group reduction side-process, as observed in other palladium-catalyzed transformations. ${ }^{11}$

Table 3. Biaryls 5 synthesized by Hiyama coupling catalyzed by complexes 1-2

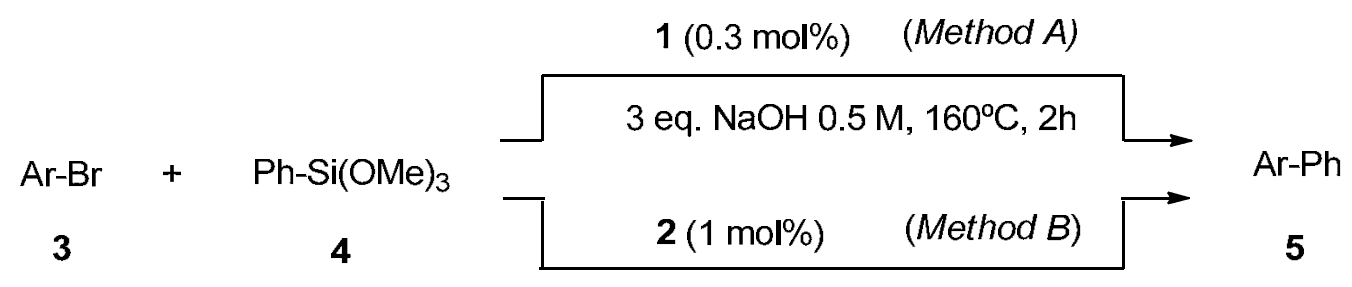

5 eq. $\mathrm{NaOH} 2 \mathrm{M}, 150^{\circ} \mathrm{C}, 2 \mathrm{~h}$

Entry

${ }^{a}$ Determined by ${ }^{1} \mathrm{H}$ NMR spectroscopy on the basis of the amount of starting aryl bromide. Diethylene glycol dimethyl ether was used as internal standard. The isolated yield of chromatographically pure compound is displayed in parentheses. ${ }^{b}$ Only traces of coupling product 5 were detected. 
Finally, recycling of the aqueous layer containing the palladium catalyst was assayed. Thus, the reaction mixture from the synthesis of biaryl 5a (Method A) was extracted with diethyl ether, and the resulting aqueous layer, without any further treatment, was poured onto a screw-capped tube, which was also charged with the reagents 3a, 4 (aqueous $\mathrm{NaOH}$ ) and heated to $160^{\circ} \mathrm{C}$ for $2 \mathrm{~h}$ as in the first run. The yield of this second run was $86 \%$, good enough considering the simplicity of the recycling procedure. A third run was also carried out, but the yield dropped to $18 \%$ in this case. It should be also pointed out the scalability of the process, as the latter recycling protocol was conducted on a 2-gram scale $(10.1 \mathrm{mmol})$ providing slightly better isolated yields for the second and third runs ( $89 \%$ and $22 \%$ respectively).

To sum up, the palladium-catalyzed coupling between several aryl bromides and phenylsilane has been conducted by using two CNC-pincer complexes of $\mathrm{Pd}(\mathrm{II})$. For both complexes, the best conditions involved a fluoride-free procedure performed in aqueous media. In addition, a comparative study of their efficiency has been carried out, proving that this "onwater" Hiyama coupling was better accomplished by using the less hydrophilic complex 1, although tricarboxylated complex 2 allowed for a lower amount of trimethoxyphenylsilane.

Finally, the reuse of the aqueous layer containing the catalyst has been also explored.

\section{Experimental Section}

General. For general experimental details, see ref. 12.

\section{Hiyama coupling catalyzed by pincer complex 1 (Method A). General procedure}

A screw-capped tube open to the atmosphere was charged with the aryl bromide $(1 \mathrm{mmol})$, complex $1(0.003 \mathrm{mmol})$ and $\mathrm{NaOH}(1 \mathrm{~mL}$ of a $0.5 \mathrm{M}$ solution in water) at room temperature. This mixture was stirred for $5 \mathrm{~min}$. In another flask, trimethoxyphenylsilane (4 mmol) was added to a $0.5 \mathrm{M}$ aqueous solution of $\mathrm{NaOH}(5 \mathrm{~mL})$ and stirring was continued for $5 \mathrm{~min}$. The latter mixture was added to the screw-capped tube, then it was sealed and heated with stirring at $160^{\circ} \mathrm{C}$ for 2 hours. After cooling, the mixture was extracted with $\mathrm{Et}_{2} \mathrm{O}(3 \times 6 \mathrm{~mL})$, and the combined organic layers were dried over anhydrous sodium sulfate and evaporated in vacuo. The resulting residue was redissolved in $\mathrm{CDCl}_{3}$ and the yield was calculated by ${ }^{1} \mathrm{H}-\mathrm{NMR}$ using diethylene glycol dimethyl ether as internal standard. Purification by Flash column chromatography using $10 \%$ ethyl acetate/hexane as eluent was performed when indicated.

Following this procedure the following products were prepared:

1-Biphenyl-4-yl-ethanone (5a) ${ }^{13}$ (>99\%, chromatographically pure, 99\% isolated yield). ${ }^{1} \mathrm{H}$ $\operatorname{NMR}\left(\mathrm{CDCl}_{3}\right) \delta(\mathrm{ppm}): 2.64(\mathrm{~s}, 3 \mathrm{H}), 7.40$ (t, $\left.J=7.0 \mathrm{~Hz}, 1 \mathrm{H}\right), 7.48(\mathrm{t}, J=7.5 \mathrm{~Hz}, 2 \mathrm{H}), 7.63(\mathrm{t}, J=$ $4.5 \mathrm{~Hz}, 2 \mathrm{H}), 7.69(\mathrm{~d}, J=4.0 \mathrm{~Hz}, 2 \mathrm{H}), 8.03(\mathrm{~d}, J=8.4 \mathrm{~Hz}, 2 \mathrm{H}) ;{ }^{13} \mathrm{C}-\mathrm{NMR}\left(\mathrm{CDCl}_{3}\right) \delta(\mathrm{ppm}): 26.9$, $127.3,127.3,128.3,128.9,129.0,135.9,139.9,145.8,197.7$. 
4-Nitrobiphenyl (5b) ${ }^{13}(18 \%) .{ }^{1} \mathrm{H}-\mathrm{NMR}\left(\mathrm{CDCl}_{3}\right) \delta(\mathrm{ppm}): 7.46(\mathrm{t}, J=7.2 \mathrm{~Hz}, 1 \mathrm{H}), 7.51(\mathrm{t}, J=$ $7.5 \mathrm{~Hz}, 2 \mathrm{H}), 7.64$ (d, $J=7.0 \mathrm{~Hz}, 2 \mathrm{H}), 7.75(\mathrm{~d}, J=9.0 \mathrm{~Hz}, 2 \mathrm{H}), 8.32(\mathrm{~d}, J=9.0 \mathrm{~Hz}, 2 \mathrm{H}) ;{ }^{13} \mathrm{C}-$ NMR $\left(\mathrm{CDCl}_{3}\right) \delta(\mathrm{ppm}): 147.6,147.1,138.8,129.2,128.91,127.8,127.4,124.1$.

Biphenyl-4-carbonitrile (5c) ${ }^{13}(87 \%) .{ }^{1} \mathrm{H}-\mathrm{NMR}\left(\mathrm{CDCl}_{3}\right) \delta(\mathrm{ppm}): 7.42(\mathrm{~m}, 1 \mathrm{H}), 7.48(\mathrm{t}, J=7.5$ $\mathrm{Hz}, 2 \mathrm{H}), 7.59$ (t, $J=4.5 \mathrm{~Hz}, 2 \mathrm{H}), 7.68(\mathrm{~d}, J=8.5 \mathrm{~Hz}, 2 \mathrm{H}), 7.73(\mathrm{~d}, J=8.5 \mathrm{~Hz}, 2 \mathrm{H}) ;{ }^{13} \mathrm{C}-\mathrm{NMR}$ $\left(\mathrm{CDCl}_{3}\right) \delta(\mathrm{ppm}): 110.8,118.9,127.1,127.6,128.6,129.0,132.5,139.0,145.5$.

4-Methoxybiphenyl (5d) ${ }^{13}(45 \%) .{ }^{1} \mathrm{H}-\mathrm{NMR}\left(\mathrm{CDCl}_{3}\right) \delta(\mathrm{ppm}): 3.86(\mathrm{~s}, 3 \mathrm{H}), 6.98(\mathrm{~d}, 2 \mathrm{H}, J=4.3$ $\mathrm{Hz}), 7.28(\mathrm{t}, 1 \mathrm{H}, J=14.8 \mathrm{~Hz}), 7.42(\mathrm{t}, 2 \mathrm{H} . J=7.7 \mathrm{~Hz}), 7.54(\mathrm{q}, 4 \mathrm{H}, J=6.7 \mathrm{~Hz}) ;{ }^{13} \mathrm{C}-\mathrm{NMR}$ $\left(\mathrm{CDCl}_{3}\right) \delta(\mathrm{ppm}): 55.3,114.1,126.5,126.6,128.0,128.6,133.7,140.7,159.0$.

3-Methoxybiphenyl (5e) ${ }^{14}(30 \%) .{ }^{1} \mathrm{H}-\mathrm{NMR}\left(\mathrm{CDCl}_{3}\right) \delta(\mathrm{ppm}): 3.83(\mathrm{~s}, 3 \mathrm{H}), 6.88(\mathrm{dd}, J=7.8,1.6$ $\mathrm{Hz}, 1 \mathrm{H}), 7.12(\mathrm{t}, J=1.6 \mathrm{~Hz}, 1 \mathrm{H}), 7.16(\mathrm{dd}, J=7.8,1.6 \mathrm{~Hz}, 1 \mathrm{H}), 7.31-7.35(\mathrm{~m}, 2 \mathrm{H}), 7.41(\mathrm{t}, J=$ $7.8 \mathrm{~Hz}, 2 \mathrm{H}), 7.57(\mathrm{~d}, J=7.8 \mathrm{~Hz}, 2 \mathrm{H}) ;{ }^{13} \mathrm{C}-\mathrm{NMR}\left(\mathrm{CDCl}_{3}\right) \delta(\mathrm{ppm}): 55.3,122.6,112.8,119.6$, $127.1,127.3,128.6,129.6,141.0,142.6,159.8$.

4-Methylbiphenyl (5f) ${ }^{13}$ (85\%). ${ }^{1} \mathrm{H}-\mathrm{NMR}\left(\mathrm{CDCl}_{3}\right) \delta$ (ppm): 2.39 (s, 3H), 7.25 (d, $J=7.5 \mathrm{~Hz}$, 2H), 7.32 (t, $J=7.3 \mathrm{~Hz}, 1 \mathrm{H}), 7.43$ (d, $J=7.5 \mathrm{~Hz}, 2 \mathrm{H}), 7.49$ (d, $J=8.0 \mathrm{~Hz}, 2 \mathrm{H}), 7.58$ (d, $J=7.5$ $\mathrm{Hz}, 2 \mathrm{H}) ;{ }^{13} \mathrm{C}-\mathrm{NMR}\left(\mathrm{CDCl}_{3}\right) \delta$ (ppm): 21.2, 127.1, 127.2, 128.8, 129.6, 137.1, 138.5, 141.3.

\section{Hiyama coupling catalyzed by pincer complex 2 (Method B). General procedure}

A screw-capped tube open to the atmosphere was charged with the aryl bromide $(1 \mathrm{mmol})$, complex $2(0.01 \mathrm{mmol})$ and $\mathrm{NaOH}(1 \mathrm{~mL}$ of a $2 \mathrm{M}$ solution in water $)$ at room temperature. This mixture was stirred for $5 \mathrm{~min}$. In another flask, trimethoxyphenylsilane $(1.2 \mathrm{mmol})$ was added to a $2 \mathrm{M}$ aqueous solution of $\mathrm{NaOH}(5 \mathrm{~mL})$ and stirring was continued for $5 \mathrm{~min}$. The latter mixture was added to the screw-capped tube, then it was sealed and heated with stirring at $150^{\circ} \mathrm{C}$ for 2 hours. After cooling, the mixture was extracted with $\mathrm{Et}_{2} \mathrm{O}(3 \times 6 \mathrm{~mL})$, and the combined organic layers were dried over anhydrous sodium sulfate and evaporated in vacuo. The resulting residue was redissolved in $\mathrm{CDCl}_{3}$ and the yield was calculated by ${ }^{1} \mathrm{H}-\mathrm{NMR}$ using diethylene glycol dimethyl ether as internal standard.

Following this procedure the following products were prepared:

1-Biphenyl-4-yl-ethanone $\left.\mathbf{( 5}^{\mathbf{a}}\right)^{13}$ (>99\%, chromatographically pure, $99 \%$ isolated yield)

4-Methoxybiphenyl (5d) ${ }^{13}(60 \%)$

3-Methoxybiphenyl (5e) ${ }^{14}(11 \%)$.

4-Methylbiphenyl (5f) ${ }^{13}(6 \%)$

\section{Acknowledgements}

This research was supported by the University of the Basque Country/Basque Government (Projects GIC10/52/IT-370-10 and S-PC08UN04) and the Spanish Ministry of Education and Science (MICINN CTQ2010-20703/BQU). B.I. and M.J.M. thank the University of the Basque Country (UPV/EHU) for predoctoral scholarships. The authors also thank Petronor, S.A. for 
generous donation of hexane. Finally, technical and human support provided by SGIker (UPV/EHU, MICINN, GV/EJ, ESF) is acknowledged.

\section{References and Notes}

1. (a) Hatanaka, Y.; Hiyama, T. J. Org. Chem. 1988, 53, 918. (b) Hiyama, T. J. Organomet. Chem. 2002, 653, 58.

2. Murata, M.; Shimazaki, R.; Watanabe, S.; Masuda, Y. Synthesis 2001, 2231.

3. See for example: (a) Dash, C.; Shaikh, M. M.; Ghosh, P. Eur. J. Inorg. Chem. 2009, 1608. (b) Alacid, E.; Nájera, C. J. Org. Chem., 2008, 73, 2315. (c) Gordillo, I.; de Jesús, E.; LópezMardomingo, C. Org. Lett., 2006, 8, 3517. (d) So, C. M.; Lee, H. W.; Lau, C. P.; Kwong, F. Y. Org. Lett., 2009, 11, 317. (e) Zhang, L.; Wu, J. J. Am. Chem. Soc. 2008, 130, 12250.

4. (a) Napier, S.; Marcuccio, S. M.; Tye, H.; Whittaker, M. Tetrahedron Lett. 2008, 49, 3939.

(b) Inés, B.; SanMartin, R.; Churruca, F.; Domínguez, E.; Urtiaga, M. K.; Arriortua, M. I. Organometallics 2008, 27, 2833.

5. (a) Morales-Morales, D.; Jensen, C. M. Eds.; The Chemistry of Pincer Compounds; Elsevier: Amsterdam, 2007. (b) Albrecht, M.; van Koten. G. Angew. Chem. Int. Ed. 2001, 40, 3750. (c) van der Boom, M. E.; Milstein. D. Chem. Rev. 2003, 103, 1759. (d) Serrano-Becerra, J. M.; Morales-Morales, D. Curr. Org. Synth. 2009, 6, 169. (e) Singleton. J. T. Tetrahedron 2003, $59,1837$.

6. Inés, B.; Sanmartin, R.; Moure, M. J.; Domínguez, E. Adv. Synth. Catal. 2009, 351, 2124.

7. See for example: (a) Carril, M.; SanMartin, R.; Domínguez, E. Chem. Soc. Rev. 2008, 37, 639. (b) Churruca, F.; SanMartin, R.; Inés, B.; Tellitu, I.; Domínguez, E. Adv. Synth. Catal. 2006, 348, 1836.

8. Polyethylene glycols (PEGs), also known as polyethylene oxides (PEOs) or polyoxyethylenes (POEs), have been extensively used as biodegradable, non-toxic solvents in a plethora of applications (generally depending on their molecular weight) from industrial manufacturing to medicine. For an example of the use of these sustainable solvents, see: Liu, L.; Zhang, Y.; Wang, Y. J. Org. Chem. 2005, 70, 6122.

9. For a more detailed discussion on the formation and participation of palladium nanoparticles from CNC pincer complexes in Suzuki-type cross couplings, see reference 6. A mercury drop test was conducted in these Hiyama couplings presumably catalyzed by complexes 1-2 (0.3-1 $\mathrm{mol} \%$ of $\mathrm{Pd}$ ), and no reaction was observed under the latter conditions. However, these results must be considered as preliminary, and further experiments should be performed (see for example Ref. 6) for a better understanding of the real role of such pincer complexes.

10. In fact, complex 2 is completely soluble in aqueous alkaline conditions while slightly soluble at neutral $\mathrm{pH}$. Complex $\mathbf{1}$ is slightly soluble in both at room temperature. 
11. See, for example: (a) Kwong, F. Y.; Lai, C. W.; Tian, Y.; Chan, K. S. Tetrahedron Lett. 2000, 41, 10285. (b) Churruca, F.; SanMartin, R.; Carril, M.; Tellitu, I.; Domínguez, E. Tetrahedron 2004, 60, 2393.

12. Olivera, R.; SanMartin, R.; Domínguez, E.; Solans, X.; Urtiaga, M. K.; Arriortua, M. I. J. Org. Chem. 2000, 65, 6398.

13. Liu, L.; Zhang, Y.; Wang, Y. J. Org. Chem. 2005, 70, 6122.

14. Inamoto, K.; Kuroda, J.; Hiroya, K.; Noda, Y.; Watanabe, M.; Sakamoto, T. Organometallics 2006, 25, 3095. 